\title{
The Assessment of the Economic Disparities in the Slovak Republic
}

\author{
Katarína Havierniková1 ${ }^{1}$, Dana Jašková1 ${ }^{1}$ Jana Masárová1 \\ ${ }^{1}$ Alexander Dubček University of Trenčín, Slovakia
}

\begin{abstract}
The exploring of regional disparities is at the center of researchers' interest in relation to socio-economic changes and globalization processes. The paper is focused on evaluation of regional disparities among eight Slovak regions with the focus on economic indicators. The evaluated indicators will be: employment rate, unemployment rate, long-term unemployment rate, average nominal monthly wage, net money income, labor productivity, gross fixed capital formation on GDP, foreign direct investment per capita, the R\&D expenditure per capita, road network density (motorways and expressways), regional gross domestic product per capita. The study was realized by creation of Composite indicator (CI) and Gini Index (GI) calculation and provide framework for regional development assessment. The results of our study could contribute to the more effective implementation of regional policy instruments.
\end{abstract}

Keywords: disparities, region, indicators, economic indicators

\section{Introduction}

The term of regional disparities is often used but its explanation is understood in different ways. In general, the regional disparities are understood as the inequalities or the differences, while their difference is measurable. In the case of regional development, the term of disparity is understood as the different degrees of economic and social development, which create inequalities between the compared units. The term of disparity is necessary to understood in wider context, due to the fact, that disparities doesn't cover only social and economic dimension, but also the spatial, geographical political, social and ecological disparities. This confirmed Výrostová (2010), who argued that the disparities have economic, social and political character. Various literature sources present, that disparities are seen in positive as well as the negative ways. The 
positive disparities represent the determining force for the development of the region. They determine and differentiate the regional development. From the negative perspective, the disparities represent socially undesirable differences. The regional disparities could be caused by economic as well as the non-economic factors: the low mobility of labor and capital, insufficient use of production factors and many others. As Betáková et al. (2015) stated, the increasing of the efficiency and complexity of land use and targeted process of sustainable development also entails increasing attention. When dealing with regional disparities, we must take into account: the causes of their origin and development, their impact on the population, economic development and the environment, the ways of disparities' measuring and the possibility how they could be influence by regional policy instruments. The research in this paper is focused on economic disparities, measured by several indicators, which represent the differences between the quality and quantity of regions' output.

Regional disparities by constantly changing and evolving can be measured, as well as evaluated. Koziak et al. (2014) stated that the application of various statistical tools and measures to measure disparities can be found in the literature: standard deviation, coefficient of variation, the Lorenz curve, Gini Index, Theil index, cluster analysis and others. To gain main aim of this paper, for the assessments of regional disparities, the cluster analysis and Gini Index will be use. By using of the cluster analysis, we will identify the regions, which are similar from the point of view of compared economic indicators. Gini coefficient is probably the most popular summary inequality measure, used vastly in individual-level income studies, but also for purposes of regional inequality analysis (Puljiz and Maleković, 2007).

The paper is organized as follows. In next chapter, the literature review focused on issues of regional disparities is presented. The part of Methods and Data provides a brief of realized analysis. This part contains the explanation of applied disparities measures and data sources. The results of realized analyses are presented in part Results and Discussion. The last chapter presents the conclusions with implications for future research.

\section{Literature Review}

Some authors refer unified name for regional disparities, as the social and economic disparities. Social disparities are very closely linked to economic. Regional inequalities that occur are mostly in the form of unequal social and economic opportunities, as well as marked disparities in prosperity levels among regions (Mavraki et al., 2020). The economic disparities are one of the main regional problems. They are the focus of regional economic researches, but also the precondition and starting point for governments to formulate regional economic policies ( $\mathrm{Li}$ and Guo, 2017). Their origin is influenced by: the economic, social and rural development problems; "dual economy" in regions with high level of foreign investors, where is an isolated development of foreign and domestic companies; regional innovation backwardness, the lack of research excellence, low level 
of creativity, poor innovation support and lack of strategic direction for regions; the partial support of regions, fragmentation of support into a wide range of activities (Buček et al., 2010). Habánik (2016) identifies different historical, geographical, natural, socioeconomic and other conditions as the causes of different levels of regions, as well as having basic development factors: skills and qualifications of the workforce, financial capital and assets, land, natural and raw material resources. Many researchers pointed mainly on their negative form as uneven development of the region. Uneven socioeconomic development, which is observed at all levels - from the global to the municipal - is one of the most important issues in the world economy (Gubanova and Kleshch, 2019). The economic disparities results in a reduction of the economic growth, a decrease in production, a decreasing of living standard and the increasing of unemployment. The positive perception can be seen as a means of increasing the competitiveness and sustainability of regional development. In this context, it is necessary to take into account also the interpretation of term "region". According Gubanova and Kleshch (2019) region, on the one hand, is a complex system with the properties of openness, nonequilibrium and nonlinearity, and on the other hand, a part of space with its inherent properties (density, location, mutual arrangement of space objects, structurality, hierarchy, etc.). The economic disparities consist of: the economic potential that include the economic performance, productivity and external relations; the economic structure, which includes the economic branches' structure and the structure of entities; the development potential, which includes R\&D, foreign capital and investment; the human potential that is created by the economically active population, employment, unemployment and mobility.

There are a number of indicators to assess the regional disparities. In general, we can divide them according to their nature into economic, socio-economic, demographic and infrastructure equipment indicators. At present, multi-criteria assessment of regions is preferred. This assessment is a more objective approach than an assessment based on the single indicator. The key role of regional disparities research is the correct selection of indicators, the way of their integration into one indicator (composite indicator) and the subsequent correct interpretation of the results (Michálek, 2014). For the determination of differences among regions, it is necessary to choose the appropriate indicator or group of indicators. The most widely used indicator is the gross domestic product per capita, which is also a key indicator of regional economic performance. Next, often used indicator is the average monthly wages. Both indicators have the potential to describe except the performance of economy, also the living standards in regions. The value of work means a positive work-life balance for employees (Mura et al., 2019). Various research studies are focused on observation of economic indicators from several points of view, while explain their value for research. Kutscherauer (2011) used ten relevant indicators for assessment of affecting the development of the economic sphere of regions: net disposable income of households per capita, the gross domestic product of whole region, the gross domestic product per capita, the gross fixed capital formation per capita, the export share in the region's gross domestic product, the number of entrepreneurs (registered units) per 1,000 inhabitants, R\&D expenditure per capita, gross value added per capita, registered unemployment rate, the share of the region in total foreign direct investment. Kebza et al. 
(2019) used five indicators that represent economic level of regions: gross domestic product per capita, average monthly wages, unemployment rate, the share of workforce employed in agriculture and transport infrastructure. All the economic indicators were set in such a manner that their highest significance reached the positive poles. According Cziráky et al. (2006), there are several different approaches to regional development level assessment in the literature, the bridge often some form of classification and data reduction is employed, but they also pointed on the multivariate methodological framework based on multiple indicators of regional development assessment. Pittau et al. (2010) investigated the role of economic variables in predicting regional disparities in reported life satisfaction of European Union citizens. They used as the group-level predictors, the regional per capita gross domestic product and regional unemployment. They argued that these two economic variables, along with the rate of inflation, have been most thoroughly investigated and recognized as the most influential.

Based on the literature review, Ohlan (2013) recommends to follow main properties of good socio-economic development indicators used for assessments: firstly, a good indicator must be relevant to the process or component of development and should be as much as possible representative of the component of development it reflects; secondly, an indicator should be comprehensive in the sense that it should reflect as many aspects of the component of development, which it represents, as possible; thirdly, a good indicator should have the same direction of change as the process being measured, in our case, economic development; fourthly, the indicator should be quantifiable; fitly, a good indicator according a point of reference against which the value of the indicator can be assessed, must be scaled; sixthly, the indicators being restricted or unrestricted.

In our analysis, we focused on a narrower selection of indicators, but we assume that this will also provide a sufficient picture of the development of regional disparities in Slovakia. A very important prerequisite for the economic performance and success of an individual region is the favorable situation on the labor market. Employment, unemployment, longterm unemployment and average wage are important labor market indicators. The employment rate represents the share of employment in the total economically active population. In the identification of regional employment disparities, the methods of finding a hidden structure is widely applied. The application of these methods is determined by variability and relationships between them (Vojtková, 2010). Unemployment rate may indicate potential structural problems in the region or, on the contrary, accentuate its high economic performance. The main distinctive features of unemployment are regional disproportions, risk of increasing long-term unemployment, risk of structural unemployment, insufficient link of the education process with the needs of the labour market, burden of unemployment, insufficient innovation capacity that would support employment, and employability of excluded groups including the young. It is a general interest to tackle the unfavorable state of unemployment in all age groups (Kordoš and Krajňáková, 2018; Svabova et al., 2019). Employment and unemployment are one of the most prevalent concepts in the economy and point to the complex challenges of the market economy. They do not only express the problems of the economic 
direction, they often express the imbalance of the social and political problems of the given economy in the country (Petrušová et al., 2018). Long-term unemployment is a particular problem within unemployment. The long-term unemployment rate expresses the percentage of persons unemployed for more than one year in the number of economically active persons. Average nominal monthly wage is one of the basic socioeconomic indicators by which we can assess the differentiated development of regions. This is the average monthly wage in enterprises with 20 or more employees (Matlovič et al., 2008). The average monthly wage is the average level of gross monthly wages of employees and it is an important factor in living standards (Koišová, 2015). It is the largest part of household income. The indicator net money income becomes to another descriptors of the living standard. Net money income consists of net labor income (excluding tax income and compulsory contributions), social income, other income (property income, income from institutions and income from private persons, including income in kind, income sales of agricultural products and incomes from abroad), positive difference between collected savings and deposited deposits and positive difference between collected and paid loans (Matlovič et al., 2008). As Škrovánková et al. (2018) stated, the society is moving forward, raising living standards, increasing income, declining unemployment, but the problem is that these conditions are not equally accessible for everyone across the regions. As we mentioned above, human resources are an important factor in the development of the region, and the effectiveness of their using is reflected in labor productivity. The labor productivity indicator is another indicator by which the efficiency of the use of the labor factor can be expressed. Productivity is a source of intense economic growth and at the same time creates conditions for future employment growth if the rate of labor productivity growth is higher than that of wages (Němec et al., 2010). The next important prerequisite for economic development are investments. Investments (gross fixed capital) significantly determine the dynamics of economic development, long-term economic growth and thus also the overall economic level of a given country and its individual regions. Foreign direct investment is of particular importance for regional development. Foreign direct investment is a global phenomenon whose share in international business is steadily rising and generates large capital injections. They have been and continues to be an important factor also in regional development. They help create new jobs, which can lead to an influx of new technologies, and in total they provide the necessary capital to restore a successful transition to the market economy (Shuyan and Fabuš, 2019). As mentioned by Ivanová (2013), their localization in under-economically and socially developed regions brings a synergistic effect for the whole economy. Through the transfer and introduction of new technologies, FDI ensures the creation of new jobs (Krajčo, 2014) and increases the production potential of the region (Sochul'áková, 2014). It is precisely the rapid and efficient acquisition of new knowledge and its application in new products, technologies and services that require sufficient expenditure on science and research. The intensity of R\&D expenditures in value-added emerge as the most effective factors enhancing the growth of GDP per capita (Sterlacchini, 2008). 
Prerequisite for economic growth and sufficient foreign direct investment is built infrastructure. An indicator with the function of some sort of economic catalyst is transport infrastructure or major roads density (Kebza et al., 2019). In the Slovak Republic, transport infrastructure is included among eight identified significant critical infrastructure sectors that are strategically important for the maintenance of vital societal functions, health, safety, security, economic or social well-being of people, and the disruption or destruction of which would have a significant impact in the state as a result of the failure to maintain those functions (Luskova et al., 2016).

All the above factors affect the overall performance of the region, which is expressed by indicator of gross domestic product. It is the value of the final products and services produced in the territory of the region in a given year. Its level depends on regional resources and the effectiveness of used sources.

\section{Methods and Data}

This paper evaluates the economic regional disparities based on 11 officially stated indicators (by the Statistical Office of the Slovak Republic) for the period 2006-2017. There is the overview of indicators, their designation, type and unit in the table 1.

Tab. 1: The list of indicators

\begin{tabular}{|c|l|c|c|c|}
\hline sign & \multicolumn{1}{|c|}{ Indicator } & Abbreviation & Type & Unit \\
\hline $\boldsymbol{y}_{\mathbf{1}, \boldsymbol{r}}$ & employment rate & 1_ER & $\max$ & $\%$ \\
\hline $\boldsymbol{y}_{\mathbf{2}, \boldsymbol{r}}$ & unemployment rate & 2_UR & $\min$ & $\%$ \\
\hline $\boldsymbol{y}_{\mathbf{3}, \boldsymbol{r}}$ & long-term unemployment rate & 3_LTUR & $\min$ & $\%$ \\
\hline $\boldsymbol{y}_{\mathbf{4}, \boldsymbol{r}}$ & average nominal monthly wage & 4_ANMW & $\max$ & $€$ \\
\hline $\boldsymbol{y}_{\mathbf{5 , r}}$ & net money income & 5_NMI & $\max$ & $€$ \\
\hline $\boldsymbol{y}_{\mathbf{6}, \boldsymbol{r}}$ & labour productivity & 6_LP & $\max$ & $€$ \\
\hline $\boldsymbol{y}_{\mathbf{7}, \boldsymbol{r}}$ & gross fixed capital formation on GDP & 7_GFC & $\max$ & $€$ \\
\hline $\boldsymbol{y}_{\mathbf{8}, \boldsymbol{r}}$ & foreign direct investment per capita & 8_FDI & $\max$ & $€$ \\
\hline $\boldsymbol{y}_{\mathbf{9}, \boldsymbol{r}}$ & the R\&D expenditure per capita & 9_RDE & $\max$ & $€$ \\
\hline $\boldsymbol{y}_{\mathbf{1 0}, \boldsymbol{r}}$ & road network density (motorways and expressways) & 10_RND & $\max$ & $\mathrm{km} / \mathrm{km} 2$ \\
\hline $\boldsymbol{y}_{\mathbf{1 1}, \boldsymbol{r}}$ & regional gross domestic product per capita & 11_RGDP & $\max$ & $€$ \\
\hline
\end{tabular}

Source: Authors.

\section{The construction of Composite indicator (CI)}

Based on the indicators stated in the Tab. 1, for the main aim of this paper's achieving, the Composite indicator (CI) was constructed. In general, the CI is indicator, which is constructed from several sub-indicators, which are often non-directional, have different levels and variability, and exhibit different degrees of interdependence in pairs. Subindicators assess the region from different, often ambiguous, perspectives. The CI, constructed from these sub-indicators, should allow a more comprehensive, coherent and synthesizing view of the level of regions in the country (Minařík et al., 2013). The OECD (OECD, 2008) published a detailed methodology for construction of CI. The OECD's 
Handbook on Constructing Composite Indicators describes different methodologies that can be applied to combine varied information into this index and the difficulties associated with each part of the process. Methods for the compilation of CIs include direct aggregation techniques, methods used for data purification, their modification, statistical processing and control of the obtained results and their presentation. A well-designed composite indicator should always include sub-trends but also contradictory developments of individual sub-indicators and factors. When constructing the composite indicator, it is important to follow the correct definition of the measured characteristics and also from the knowledge of the essential links of the problem (Hrach and Mihola, 2006).

The following steps can describe the construction of $\mathrm{CI}$ : creation of a theoretical framework, selection and combination of input indicators, assessment of their material significance, statistical characteristics, weighting, normalization, aggregation, relation to input indicators, visualization of results. Summary indicators have both advantages and disadvantages. Saisana and Tarantola (2002) discuss them in detail.

In this paper we will use the following designation: $y_{i, t}^{r}$ - the original value of the indicator $i$, of the region $r ; r=1, \ldots, R$, in year $t$ (2006 - 2017), where $i=1, \ldots, n ;(n=11), I_{i}^{t}$ is normalized indicator value $i$ in year $t$, using method Min-Max. Formula for computation of value $C_{t}^{r}$ over time tis:

$$
C I_{t}^{r}=\frac{\sum_{i=1}^{n} I_{i}^{r}}{\frac{\sum_{i=1}^{n} \sum_{r=1}^{R} I_{i .}^{r}}{R}}
$$

where $R$ is number of analyzed regions, in our study is $R=8$. The CI takes values around an average of 1 . The value of $C I_{t}^{r}>1$ means that the regions is ranked better.

\section{The construction of Gini Index (GI)}

For the assessment of regional disparities in the Slovak Republic in the paper, the concept of the Gini Index (GI) is also used. The GI is used to measure the inequality of CI distribution, which comprehensively characterizes the socio-economic situation (potential) in the regions and points to the distribution of this potential across the assessed region.

The value of $\mathrm{GI}=0$ can be interpreted as an even distribution of the socio-economic potential of regions in the Slovak Republic. The value of GI converging to 1 is interpreted as a totally uneven distribution of the $\mathrm{CI}$ value, which represents the socio-economic potential of the region. The GI value in the reference year $t$ can be calculated according to the following relationship (Zvára, 2013):

$$
G I\left(C I_{t}^{1}, \ldots, C I_{t}^{R}\right)=\frac{1}{2 R \sum_{i=1}^{R} C I_{t}^{r}} \cdot \sum_{1 \leq i, j \leq R}\left|C I_{t}^{i}-C I_{t}^{j}\right|
$$

The sequence $\left(C I_{t}^{1}, \ldots, C I_{t}^{R}\right)$ s non-decreasing after re-indexing. For the resulting value of GI it applies: $0 \leq G\left(C I_{t}^{1}, \ldots, C I_{t}^{R}\right)<1$. 


\section{Results}

Within the observed period 2006-2017, the development of indicators stated in Tab. 1 was analyzed. The observed period we can divide into three sub-periods. Years 20062008 were characterized by favorable economic development when the situation at the labor market is improved. In 2009, the development of selected indicators was affected by the economic crisis, which worsened the development of all monitored indicators. Although the economic indicators have already developed positively in 2010, the indicators of the labor market continued to deteriorate, some of them until 2013. In next years, the favorable development was recorded. The positive trend was observed in case of economic performance and social indicators. Within the monitored indicators, the best evaluation was achieved by Bratislava region and the worst by Prešov region. The Bratislava region significantly differs from other regions in the evaluation of indicators e.g. regional gross domestic product per capita, foreign direct investment per capita and motorways and expressways density.

The monitored indicators have different units of measure. For analysis, their data were transformed by using Min-Max method. The comparison of regions by the monitored indicators in years 2006 and 2017 are depict by Figure 1 and Figure 2.

Figure 1: Evaluation of Slovak regions in 2006

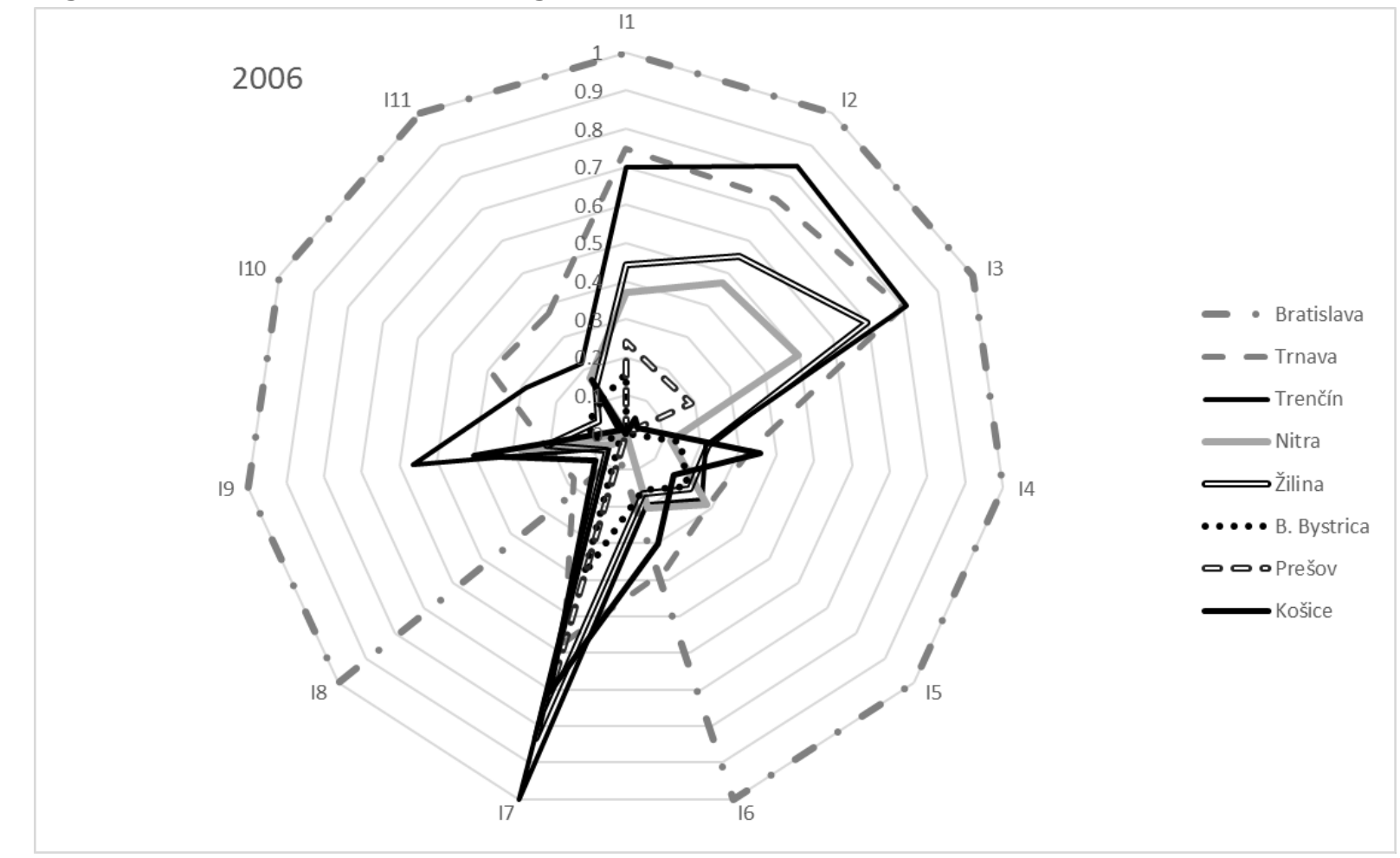

Source: Authors, based on data of the Statistical Office of the Slovak Republic. 
Figure 2: Evaluation of Slovak regions in 2017

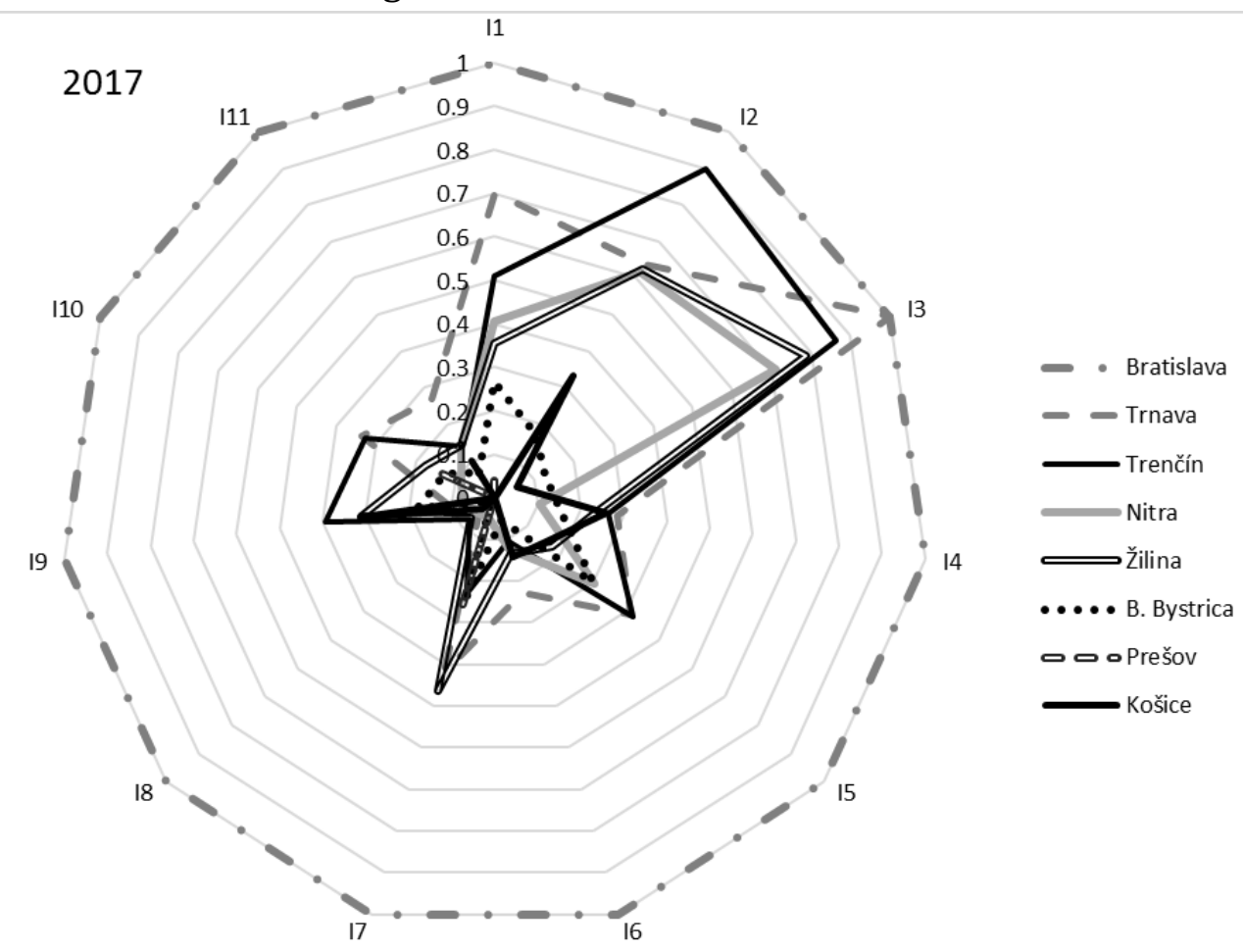

Source: Authors, based on data of the Statistical Office of the Slovak Republic.

Figure 1 and Figure 2 show a significant distance of the Bratislava region from the rest of Slovak regions, while the lagging of these regions increased in 2017. The calculated standardized values of monitored sub-indicators were used for calculation of composite indicator $C I_{t}^{r}$. The value of the composite indicator $C I_{t}^{r}$ was calculated from the analyzed indicators for each region $r$, in year $t$. There are the results for each Slovak region in the Tab. 2.

Tab. 2: The results of $C I_{t}^{r}$ and Gini Index

\begin{tabular}{|c|c|c|c|c|c|c|c|c|c|c|c|c|c|}
\hline Region & ஜ̊ & ํํㅇ & $\stackrel{\infty}{\stackrel{\leftrightarrow}{\circ}}$ & ஓి & $\stackrel{\text { Oे }}{\text { Oे }}$ & 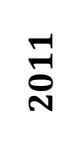 & స్ & $\stackrel{m}{\stackrel{n}{N}}$ & $\stackrel{\text { D }}{\text { D }}$ & $\stackrel{\text { L }}{\text { D }}$ & $\stackrel{0}{\stackrel{0}{*}}$ & م) & U \\
\hline Bratislava & 3.63 & 3.79 & 3.55 & 4.17 & 5.05 & 5.03 & 5.26 & 5.59 & 5.00 & 4.06 & 4.55 & 4.20 & 4.49 \\
\hline Trnava & 1.80 & 1.75 & 1.71 & 1.73 & 1.91 & 1.89 & 1.83 & 1.90 & 1.79 & 1.67 & 1.84 & 1.80 & 1.80 \\
\hline Trenčín & 1.85 & 1.62 & 1.73 & 1.72 & 1.77 & 1.64 & 1.67 & 1.73 & 1.80 & 1.51 & 1.75 & 1.87 & 1.72 \\
\hline Nitra & 0.88 & 0.93 & 1.07 & 0.80 & 0.89 & 1.09 & 1.02 & 1.07 & 1.14 & 1.05 & 1.10 & 1.16 & 1.02 \\
\hline Žilina & 1.31 & 1.40 & 1.26 & 1.24 & 1.22 & 1.38 & 1.46 & 1.37 & 1.39 & 1.58 & 1.44 & 1.40 & 1.37 \\
\hline B. Bystrica & 0.50 & 0.53 & 0.45 & 0.54 & 0.68 & 0.69 & 0.70 & 0.61 & 0.57 & 0.73 & 0.70 & 0.66 & 0.61 \\
\hline Prešov & 0.47 & 0.57 & 0.47 & 0.62 & 0.31 & 0.28 & 0.21 & 0.16 & 0.20 & 0.35 & 0.18 & 0.20 & 0.33 \\
\hline Košice & 0.83 & 0.85 & 0.95 & 0.96 & 0.76 & 0.57 & 0.64 & 0.65 & 0.66 & 0.75 & 0.58 & 0.52 & 0.73 \\
\hline $\begin{array}{c}\text { Gini } \\
\text { Index }\end{array}$ & 0.58 & 0.56 & 0.64 & 0.62 & 0.65 & 0.72 & 0.65 & 0.64 & 0.64 & 0.64 & 0.62 & 0.64 & \\
\hline
\end{tabular}

Source: Authors, based on data of the Statistical Office of the Slovak Republic. 
There is also the calculated value of GI in each observed year across all regions in Tab. 2. As it is stated above, the value of $C I>1$, represents the above-average region. The highest recorded value is $C_{2013}^{B A}=5,59$. The lowest value of the composite indicator was $C_{2013}^{P O}=$ 0,16 . The overall overview of the constructed CIs' development for each region in the observed period 2006-2017 is illustrated in Figure 3.

The regions, which are evaluated as below average in whole observed period are: Banská Bystrica, Prešov and Košice. The Nitra region could be evaluated as average in observed indicators. The regions of Žilina, Trenčín and Trnava appear to be above average. Special attention should be paid to the region of Bratislava, which is assessed as highly above average, while $\overline{C I}_{2006-2017}^{B A}=4,49$.

Figure 3: The development of CI

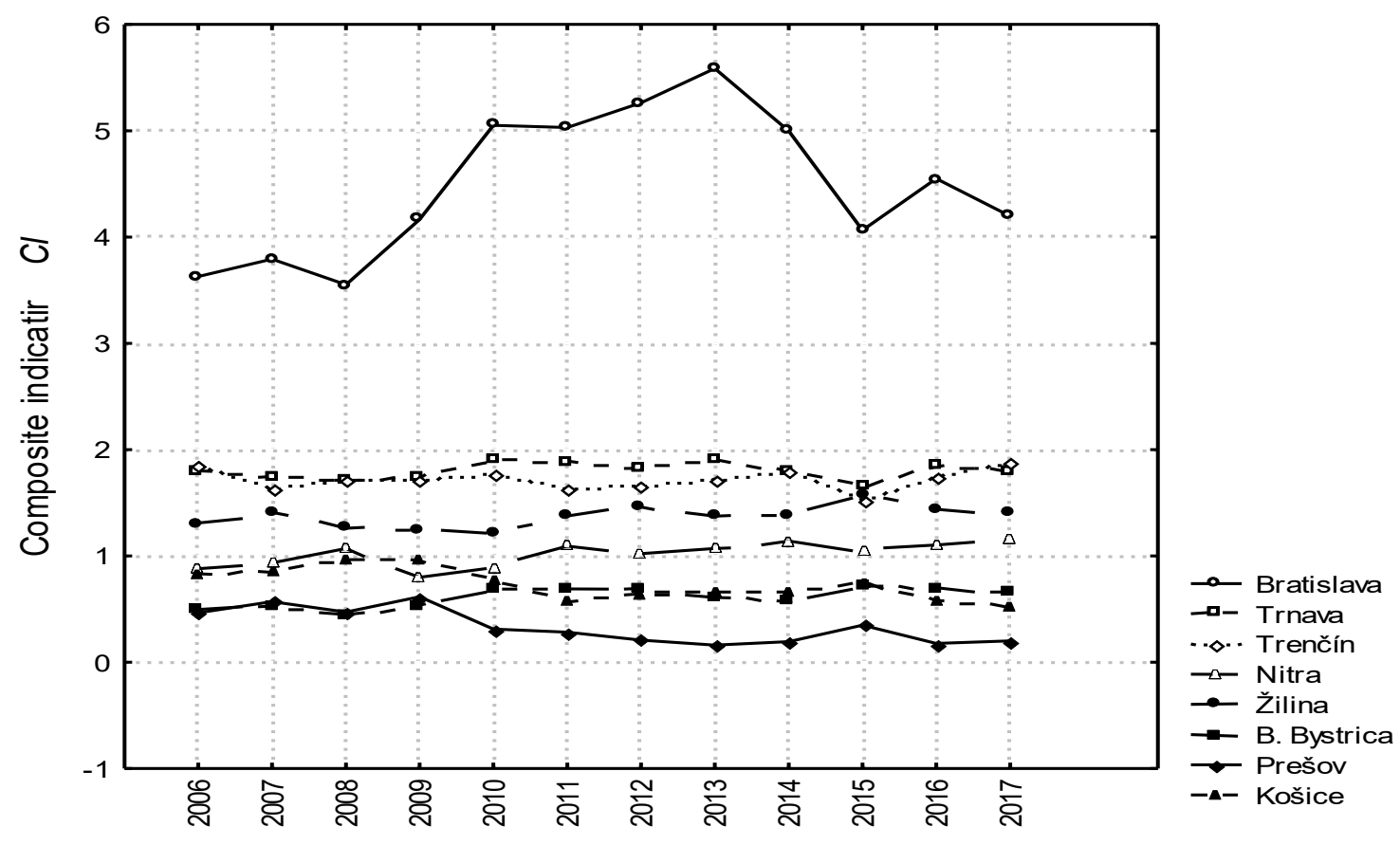

Source: Authors, based on data of the Statistical Office of the Slovak Republic.

After analysis of regions from the perspective of $C I$, the situation of the regions specified by the GI was found, in order to confirm the assumption of unequal distribution of socioeconomic "potential" of the regions. The Figure 4 shows the development of GIs value. The most even distribution was observed in 2007, when $G_{2007}=0.56$. The most uneven distribution of the socio-economic potential of the regions was in 2011, when $G I_{2011}=$ 0.72 . 
Figure 4: The development of GI

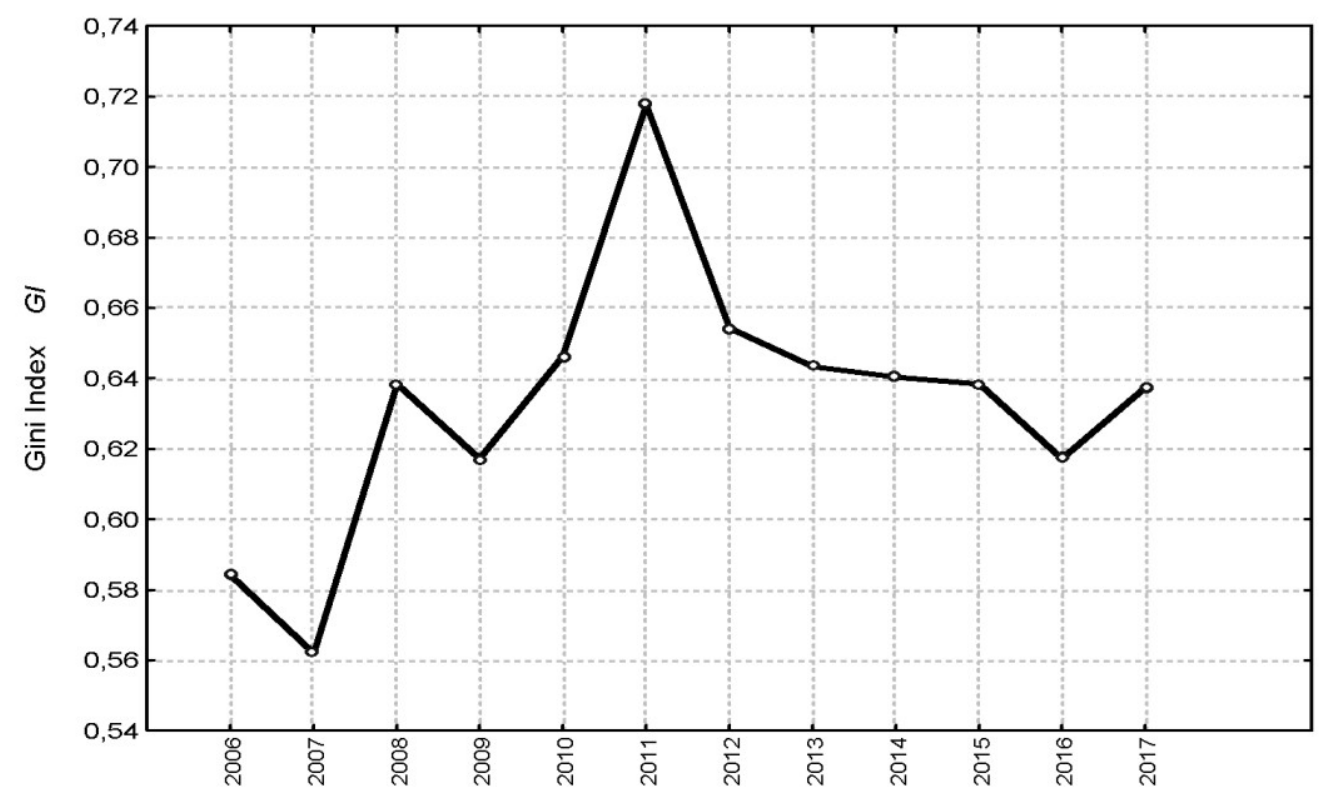

Source: Authors, based on data of the Statistical Office of the Slovak Republic.

\section{Conclusion}

Although the concept of regional disparities is often elaborated, their understanding and interpretation are inconsistent and largely diversified. This is mainly in terms of basic types of territorial disparities, attributes, user value and basic aspects of system classification and decomposition. Correct identification and measurement of regional disparities seems to be a decisive factor for solving of regional disparities. Regional disparities are characterized by a wide range of phenomena and processes that can be identified, structured, measured and evaluated.

As the results of our research based on analysis of selected economic indicators showed, years 2006-2008 were characterized by favorable economic development, but in 2009 the positively development was affected by the economic crisis and in the next years the favorable development was recorded again.

We also pointed on differential development in individual regions. The calculation of CIs for each region showed, that the best ranked regions except Bratislava are Trnava (1.80), Trenčín (1.72) and Žilina (1.37). The worst results of CI in observed period (2006-2017) achieved the Prešov region (0.33). The results of GI for eight Slovak regions calculated for each year showed the total uneven distribution of CI in 2011 (0.72).

In this paper, we proposed a methodological basis for regional economic disparities' assessment based on Composite Indicators' construction supplemented by calculation of Gini Index. 


\section{References}

1. BETAKOVA, J., T. PAVLENKO, J. DVORSKY, 2015. Safety area in terms of municipal planning. In Crisis management and solution of the crisis situatuions 2015, Konecny \& Admec (eds), Uherske Hradiste: Czech Republic. 31-37.

2. BUČEK, M., Š. REHÁK, J. TVRDOŇ, 2010. Regionálna ekonómia a politika. Bratislava: IURA etidition.

3. CZIRÁKY, D. et al., 2006. Regional development assessment: A structural equation approach. European Journal of Operational Research. 174(1), 427-442.

4. GUBANOVA E. S., V. S. KLESHCH, 2019. Overcoming socio-economic inequality as a condition for sustainable and balanced spatial development of the region. Economic and Social Changes: Facts, Trends, Forecast. 12(5), 44-57.

5. HABÁNIK, J., 2016. Región, sociálny a ekonomický rozvoj. In: Habánik, J. et al.: Zmeny $v$ hospodárskej štruktúre regiónov $S R \quad v$ rámci sociálno-ekonomického rozvoja. Trenčín: TnUAD, 7-42.

6. HRACH, K., J. MIHOLA, 2006. Metodické přístupy ke konstrukci souhrných ukazatelú. Časopis Statistika, Praha: ČSÚ, 5, 394-418.

7. IVANOVÁ, E., 2013. Priame zahraničné investície a ekonomický rast v regiónoch SR. Sociálno-ekonomická revue. 11(1), 26-35.

8. KEBZA, M., A. NOVACEK, D. POPJAKOVA, 2019. Socio-economic disparities in the Baltic States: analytical comparison and categorisation of the regions. Geographia Polonica. 92(3), 289-307.

9. KOIŠOVÁ, E., 2015. Trendy vo vývoji miezd v Slovenskej republike. Sociálnoekonomická revue. 13(3), 21-30.

10. KORDOŠ, M., E. KRAJŇÁKOVÁ, 2018. Significance of Innovation in Slovak RegionsIssues and Challenges. Ad Alta: Journal of Interdisciplinary Research. 8(1), 137-141.

11. KOZIAK, R. et al., 2014. Use of cluster analysis in the the investigation of regional disparities. In 17th International coloquium on regional sciences. (eds.) Klimova \& Zitek, Masaryk University, Hustopece, Czech Republic, proceedings paper. 37-44.

12. KRAJČO, K., 2014. Priame zahraničné investície v SR. Sociálno-ekonomická revue. 12(2), 61-67.

13. KUTSCHERAUER, A., 2011. Disparities in long-term development of regions in the Czech Republic. In $14^{\text {th }}$ International coloqium on regional sciences. Boretice, Czech Republic, 9-18.

14. LI, J., J. GUO, 2017. Evaluation of Regional Economic Disparities in Beijing-TianjinHebei Region based on Factor Analysis. In 2017 International Conference on Innovations in Economic Management and Social Science (IEMSS 2017). Atlantis Press. 814-817. 
15. LUSKOVA, M., K. BUGANOVA, B. LEITNER, 2016. Enhancing Security of Critical Infrastructure in Sector Transport.In $2^{\text {nd }}$ International conference on Social Science, Education and Human Science, (SEME, 2016), Destch Publiction Inc., Bankog, Thailand, 25-29.

16. MATLOVIČ, R., R. KLAMÁR, K. MATLOVIČOVÁ, 2008. Vývoj regionálnych disparít začiatkom 21. storočia na Slovensku vo svetle vybraných indikátorov. Regionální studia. 2(2), 2-12.

17. MAVRAKI, C. et al., 2020. Fostering regional development in eastern Macedonia and Thrace, Greece, through road transport projects. Economic Analysis and Policy. 65, 56-67.

18. MICHÁLEK, A., 2014. Vybrané metódy merania regionálnych disparít [online]. [accessed: 2020-7-1] Available from: http: https://www.sav.sk/journals/uploads/12121204Michalek.pdf

19. MINAŘÍK, B., J. BORŮVKOVÁ, M. VYSTRČIL, 2013. Analýzy v regionálním rozvoji. Př́bram: Professional Publishing.

20. MURA, L. et al., 2019. Position of Employee Benefits in Remuneration Structure. Transformations in Business \& Economics. 18(2), 156-173.

21. NĚMEC, O., A. KUCHARČÍKOVÁ, L. TULEJOVÁ, 2010. Regionálne disparity v efektívnom využívaní výrobného faktora práca. In Globalizácia a jej sociálnoekonomické dôsledky '10 - Zborník príspevkov z medzinárodnej vedeckej konferencie, Rajecké Teplice, Žilina, Žilinská univerzita. 379-385

22. OECD (2008). Handbook on Constructing Composite Indicators. Methodology and User Guide. Paris: Organisation for Economic Co-operation and development.

23. OHLAN, R., 2013. Pattern of regional disparities in socio-economic development in India: District level analysis. Social Indicators Research. 114(3), 841-873.

24. PETRUŠOVÁ, D., K. KRÁL'OVÁ, J. SOCHULÁKOVÁ, 2018. Employment and unempoyment developments in Slovakia and Czech Republic. Sociálno-ekonomická revue. 16(4), 18-26.

25. PITTAU, M. G., R. ZELLI, A. GELMAN, 2010. Economic disparities and life satisfaction in European regions. Social indicators research. 96(2), 339-361.

26. PULJIZ, J., S. MALEKOVIĆ, 2007. Regional income and unemployment disparities in Croatia. In 7th International Conference" Enterprise in transition". (eds) Reić \& Fredotović, Split, Croatia: Faculty of Economics, University of Split.

27. SAISANA, M., S. TARANTOLA, 2002. State of the art report on current methodologies and practices for composite indicator development. EUR 20408 EN, European Commission-JRC: Italy. 
28. SHUYAN, L., M. FABUŠ, 2019. Study on the spatial distribution of China's Outward Foreign Direct Investment in EU and its influencing factors. Entrepreneurship and Sustainability Issues. 6(3), 1280-1296.

29. SOCHUL'ÁKOVÁ, J., 2014. Priame zahraničné investície a ich vplyv na využitie l’udských zdrojov v regionálnom rozvoji. Sociálno-ekonomická revue. 12(2), 68-75.

30. STERLACCHINI, A. 2008. R\&D, higher education and regional growth: Uneven linkages among European regions. Research Policy. 37(6-7), 1096-1107.

31. SVABOVA, L. et al., 2019. Employability and Sustainability of Young Graduates in the Slovak Labour Market: Counterfactual Approach. Sustainability. 11(16), 4462.

32. ŠKROVÁNKOVÁ, K., E. KOIŠOVÁ, E. GRMANOVÁ, 2018. Living conditions and income inequality in the NUTS 2 regions in the Czech Republic and the Slovak Republic. Ad Alta. 8(2), 259-264.

33. VOJTKOVÁ, M., 2010. Hodnotenie zamestnanosti v regiónoch krjín V4. Ekonomické rozhl'ady. 2, 192-206.

34. VÝROSTOVÁ, E., 2010. Regionálna ekonomika a rozvoj. Bratislava: Iura Edition, spol. s.r.o.

35. ZVÁRA, K., 2013. Základy statistiky v prostredí R. Praha: Nakladatelství Karolinum.

\section{Contact address of the authors:}

Ing. Katarína Havierniková, Ph.D., Department of Economy and Economics, Faculty of Social and Economic Relations, Alexander Dubček University of Trenčín, Študentská 3, 91150 Trenčín, Slovakia, e-mail: katarina.haviernikova@tnuni.sk

RNDr. Dana Jašková, PhD., Department of Economy and Economics, Faculty of Social and Economic Relations, Alexander Dubček University of Trenčín, Študentská 3, 91150 Trenčín, Slovakia, e-mail: dana.jaskova@tnuni.sk

Ing. Jana Masárová, PhD., Department of Economy and Economics, Faculty of Social and Economic Relations, Alexander Dubček University of Trenčín, Študentská 3, 91150 Trenčín, Slovakia, e-mail: jana.masarova@tnuni.sk 